\title{
Causes and Effects of Drought in Northern Parts of Ethiopia
}

\author{
Yitbarek Andualem Mekonnen, Prof.Dr.Huseyin Gokcekus \\ Faculty of Civil and Environmental Engineering \\ Departments of civil engineering, Near East University, Mersin 10 Turkey
}

\begin{abstract}
Droughts are generally periods that rainfall is below normal, leading to extended periods of water shortage. This paper reviews the causes and consequences of drought in northern parts of Ethiopia country. Drought occurred in northern parts Ethiopia have been quasi-periodically during the last several centuries up to now. The main causes of drought in northern parts of Ethiopia are either natural or human activities or both. The effects of drought are widespread and have effects on the environment and the society as a whole, on their economy, social aspects and politics. Drought must be mitigate or reduced, drought mitigation strategies are things that can be reduce the forces or intensity of dry periods by using different mechanisms in different ways.
\end{abstract}

Keywords: drought, causes of drought, effects of drought, mitigation, Northern parts of Ethiopia

DOI: $10.7176 / \mathrm{CER} / 12-3-04$

Publication date:March $31^{\text {st }} 2020$

\section{INTRODUCTION}

\subsection{Drought}

There are two types of drought definition: 1.conceptual definition and 2. Operational definition

Conceptual definition of drought is helps to understand the meaning of drought and its effects. Operational definition of drought is helps to identify the drought's beginning, end and degree of severity.

Drought is a complicated phenomenon, which is difficult to monitor and define. One difficulty is that drought means different things in different place or regions or countries or total place to places. "Drought" is not a set number or equation. It is defined depending on the average amounts of precipitation of an area (Tannehill, 1947).

Drought is an insidious hazard of nature. It is related to a deficiency of precipitation over an extended period of time, usually for a season or more. This deficiency results in a water shortage for some activity, group or environmental sector. Drought is also related to the timing of precipitation. Other climatic factors such as high temperature, high wind and low relative humidity are often associated with drought for long or short period of time. Drought can be cause significant damage and harm to the local economy (Wilhite et al. 2006; Hisdal and Tallasken 2000).

Therefore, there is not a universal definition of drought, because it varies from place to place or region to region or person to person or country to country. Lack of objective definition of drought in a specific situation has been an obstacle to understanding drought, which has lead to effects on the part of managers, policy makers and other bodies.

Drought affects all parts of our environment and our communities. The many different drought impacts are often grouped as "economic," "environmental," and "social" impacts. All of these impacts must be considered in planning for and responding to drought conditions (WMO, 1986; NMSA, 1996).

Man has always faced weather and climate vagaries and problems related to droughts. However, the recent problems of inadequate water quantity and quality, which effectively reduced the available resources, increased the severity of water deficits. Drought-related disasters have been more devastating than other natural hazards (earthquakes, volcanoes, etc), as far as deaths, suffering and economical damages, social damages, political damages and environmental damages are concerned in northern parts of Ethiopia most of times. Apart from destructive direct effects, drought events have been followed by secondary, indirect calamities, such as famine, epidemics, fire, etc. Despite the progress in science and technology, man is still vulnerable to extreme drought events. The losses increase due to the continuing development of costly infrastructure, Rise in population density and increasing deforestation, urbanization, drainage wetlands, etc. Understanding droughts, their occurrences, mechanisms, characteristics and regularities is great importance for the design and management of water resources systems.

Drought produces a complex web of impacts that spans may sectors of the economy and reaches well beyond the area experiencing physical drought (De Waal, 1989 cited in Alemayew Kassa, 1999). This complexity exists because water is integral to society's ability to produce goods and provide services. Impacts are commonly referred to as direct and indirect. Direct impacts including reduced crop. Rangeland and forest productivity, increased fire hazard, reduced water levels, increased livestock and wildlife mortality rates and damage to wildlife and fish habitat. The consequences of these direct impacts illustrate indirect impacts. For example, a reduction in crop, rangeland and forest productivity may result in reduced income for farmers and agribusiness, increased prices for food and timber, unemployment, reduced tax revenues because of reduced expenditures, foreclosures on bank loans to farmers and businesses, migration and disaster relief programs. 
Drought can have many devastating effects on communities and the surrounding environment. The amount of devastation depends on the strength of the drought and the length of time an area is considered to be in drought conditions. Drought has greater impacts on poorer communities than on more prosperous communities who have better opportunities to bring in resources from other areas. Drought, however, can be very harsh on any types of community. One impact of drought on communities is its effect on water supply may be surface water or groundwater sources.

Drought management is a multidisciplinary area, which needs input from hydrologists, agriculturists, farmers, climatologists, soil scientists, engineers, social scientists, economists, etc. various droughts related issues need to be sorted out at the Federal level of the country in consultation with different states because the impacts of drought are widespread across the states.

Drought affects our lives in many different ways because water is such an important part of so many of our activities, like washing dishes, cooking, bathing, and swimming or river rafting. Water is also used to help make the electricity we use to run the lights in our houses and the video games you may like to play. When we don't have enough water for these activities because of a drought, many people and many different things will be affected in many different ways in northern parts of Ethiopia vary times.

\section{Types of Drought}

Different sets of people have different definitions of drought. Meteorologist define drought as a prolonged duration without rain. Crop farmers describe drought as the absence of moisture, which inhibits crop growth. Hydrologists define drought as an extended period of less precipitation and stream flow. According to Wilhite and Glantz (1985) drought can be divided into main types of droughts, which include: Meteorological drought, Hydrological, Agricultural drought, Socio-economic and Ecological drought

\subsection{Meteorological drought}

Meteorological drought is defined as a deficit in precipitation over a defined period and region as compared to climatologically average values. Meteorological drought can be characterized using meteorological data products on precipitation available from national and international weather services. Meteorological drought is generally defined by comparing the rainfall in particular place and at a particular time. This happens when the actual rainfall in an area is significantly less than the climatologically mean of that area. Meteorological drought leads to soil moisture and this always has effects on crops productions (National of Meteorology, Ethiopia Government, 2006).

\subsection{Hydrological Drought}

Hydrological drought is defines as a significant decrease in the availability of water in all its forms appearing in the land phase of the hydrological cycle (Nalbantis, 2009).

Hydrological drought is described as a sustained and regionally extensive occurrence of below average natural water availability (Tallaksen and van Lanen, 2004)

\subsection{Agricultural Drought}

Agricultural drought is typically defined as a period when soil moisture is inadequate to meet evapo-transpiration demands so as to initiate and sustain crop growth (Changnon, 1987). As such, it focuses on soil moisture deficits and differences between actual and potential evapo-transpiration (Tate and Gustard, 2002) and is primarily centered on the availability of soil moisture in the root zone of crops, though it may also refer to lack of water for plan growth to meet the needs of livestock (Changnon, 1987).

\subsection{Socio-economic Drought}

Socioeconomic drought is defined as associate the supply and demand of some economic good with elements of meteorological, hydrological and agricultural drought. It differs from the other types of drought in that its occurrence depends on the processes of supply and demand. The supply of many economic goods, such as water, forage, food grains, fish and hydroelectric power depends on the weather. Due to the natural variability of climate, water supply is ample in some years, but insufficient meet human and environmental needs in other years. This situation is sometimes compounded by rising population and explosion of demand for those goods and services to the degree that it leads to scramble for the little available water (Tallakesen and Lanen, 2004).

\subsection{Ecological Drought}

Ecological drought has been recognized only recently. It has been defined as a shortage of water causing stress on ecosystems, adversely affecting the life of plants and animals (Tallakesen and Lanen, 2004). However, unlike agricultural drought, ecological drought currently lacks specific indices to quantify it. 


\section{Drought in Northern Parts of Ethiopia (NPE)}

Drought is a recurrent phenomenon. In northern parts of Ethiopia drought has occurred quasi-periodically during the last several centuries up to now. The causes of drought are either natural or human made or both. The natural drought is the primary caused by the fluctuation of the general atmospheric circulation. As a consequence of such fluctuations the rain- producing components for northern parts of Ethiopia have been weakened during drought years. Human interferences such as deforestation, overgrazing and over cultivation enhance the severity and prolongation of drought recurrences.

While NPE battles residual needs from the 2015/2016 El Nino-induced drought, below average 2016 autumn rains in the northern parts of country have led to a new drought in lowland areas, as well as in areas across the country. As a result, some 5.6 million people in NPE require emergency food assistance in 2017. In addition, 2.7 million children and pregnant and lactating mothers require supplementary feeding, 9.2 million people need support to access adequate and safe drinking water supply, 1.9 million households need livestock support and 300,000 children between 6-59 months old are targeted for the treatment for severe acute malnutrition in 2017. Drought conditions are expected to peak during the dry December to March season, which is likely to lead to a sharper deterioration in livestock body conditions and impacting milk production and nutrition status of the families that depend on livestock for their food and income. During the dry season, the response will be complemented by supplementary food based regular screenings to ensure the most vulnerable are reached (OCHA, 17 Feb 2017).

The impacts of long term climate change on rainfall patterns have combined with the onset of the strongest El Nino climate event on record to devastating effects on food security and malnutrition across vast regions of the country and pushed people's coping mechanisms to the limits. More than 500,000 livestock died and the numbers of people in urgent need of food and adequate clean and safe water supply has been rapidly rising. Almost 8 million people received help from the Ethiopian government led safety net program in 2016. This drought is still causing the wide spread shortage of food and water stocks in northern parts of Ethiopian and surrounding countries.

Northern parts of Ethiopia are experiencing its second severe drought in less than two years. Insufficient rainfall during the 2017 rainy season has led to severe water shortages, catastrophic livestock losses, and failed crops throughout the country.

The Ethiopian government is conducting an emergency feeding program for 8 million people, but it cannot escape the situation alone. but, its refusing to admit to the existence of a food crisis in order to avoid the risk of losing foreign investments has initiated a situation with little international response, confirmed by the fact that an international appeal to help compensate for food shortage is 400 million pounds short of its target. Country director of save the children John Graham has remarked that the magnitude of the current crisis is very similar to that of the one that occurred in 1984, but that international support has not been as obtainable.

The World Bank has recently signed a \$100 million loan agreement with Ethiopia, with the purpose of providing more food to affected regions. However, as the dry season continues due to the El Nino weather conditions, additional and prolonged support will be needed to avoid large-scale loss of life. Indeed, the US Embassy has estimated that $\$ 1.2$ million in food assistance starting from October 2015 , but a more sustained and strengthened commitment is now needed, since it is predicted that the worst is yet to come in Northern parts of Ethiopia.

\section{Causes of drought in Northern parts of Ethiopia}

A drought is a period of drier than normal conditions that results in water related problems. Precipitation or rain falls in uneven patterns across the study area. The amount of precipitation at a particular location varies from year to year or month to month or time to time in study area of northern parts of Ethiopia such as Tigraye, Afar and northern parts of Amara regions.

The amount of rain and snow also varies with the seasons. In northern parts of Ethiopia, of the yearly precipitation falls during winter, early spring and in July. Even in the total amount of rainfall for a year is most of time is less than average, rainfall shortages can occur during a period when moisture is critically needed for plant growth, such as in the early summer season but in northern parts of Ethiopia is there is not enough amount of moisture and rainfall to growth different types of crop through the a year. When little or no rainfall, soils can dry out and plants and agricultural crops can be die. When rainfall or moisture is less than normal for several weeks, months or years, the flow of streams and rivers declines, water levels in lake and reservoirs fall and the depth to water in wells increases, if dry weather persists and water supply problems develop, the dry period can become a drought in northern parts of Ethiopia most of time for many years.

The major cause of drought in Northern parts of Ethiopia is natural condition and human activities. These are lack of rainfall or precipitation, human activities, drying out of surface water flow easily, climate changes or global warming, no food reserves, high food prices in markets, cattle bought at a low prices and lack of knowledge about adaptive farming techniques are most common problems which cause drought in Northern parts of Ethiopia most of time. 
1. Lack of rainfall or precipitation

The main reason for drought in northern parts of Ethiopia is low or lack of precipitation or rainfall. If a region or area goes for a long period of time without much rainfall, water deficiency occurs in that area and becomes dry out, especially for more than a season, then the situation leads to dry conditions and water deficient for crop growth in given area which qualify as drought. The quantity of water vapor in the atmosphere pretty much impacts the precipitation of an area. When a region has moist and low pressure systems, there is huge probability that rain, hail and snow will occur. The exact opposite would happen when the region has pressure systems and less water vapor. Farmers plant crops in anticipation of rains and so when the rains fail and irrigation systems are not in place, due to these reason agricultural droughts is happens.

2. Human activities

Human activities play a relatively significant role in the management of the water cycle. Human acts such as deforestation, overgrazing, over cultivation, construction and agriculture negatively impact on water cycle. Tree and vegetation cover are essential for the water cycle as it helps to limit evaporation, stores water and attracts rainfall and also contribute a great deal of atmospheric moisture in the form of transpiration.

In this sense, deforestation implies that clearing vegetation cover and cutting down trees increases evaporation and less the ability of soil to hold water leading to increased susceptibility of desertification. Deforestation can also influence the occurrence of dry conditions since it reduces forest's watershed potential. Construction and agricultural activities may as well reduce the overall supply quantity of water, resulting in dry spells. Over-farming is another human activity contributing to droughts. Over-farming loss the soil allowing erosion to take place, Soil erosion compromises the capacity of soil to hold water, most of time in northern parts of Ethiopia.

3. Drying out of surface water flow

Small Lakes, rivers and streams are the primary suppliers of downstream surface water in various geographical regions around the study area. In extremely hot seasons or because of certain human activities, these surface water flows are dry out downstream contributing to drought, meaning the demands for water supply become higher than the available water. Excess amount of irrigation systems and hydroelectric dams are just some of the human activities that contribute significantly diminish the amount of water flowing downstream to other areas.

4. Climate change and Global warming

Climate change or human actions have contributed to more and more emissions of greenhouse gases into the atmosphere thus resulting in the continued rise of the earth's average temperatures. Consequently, evaporation and evapo-transpiration levels have risen and the higher temperatures have led to wildfires and extended dry spell periods. The global warming situation tends to the drought conditions.

5. Lack of knowledge about adaptive farming techniques

Through no fault of their own, some farmers have not diversified their crops over the years. This may be because they only know how to grow staples, they do not have access to different seeds, or they do not understand different farming techniques. Relying on a single crop can leave a farmer vulnerable to the impact of extreme weather. This causes the dry of the land and water from the land and change the climate around it.

Generally, cause of drought in northern parts of Ethiopia is both natural and human activities. Natural phenomenon is most of time the precipitation and rainfall is very low compare to other parts of country and coming of rain is not keeping the crop growing seasons and also vary from season to season and year to year. Human activities, most of time lack of awareness of deforestation of trees, planting new tress, way of farming the land and exchanges of seeds of crop year to year and does not using new technology of farming and there is no other alternative resource instead of farming around this area.

\section{Effects of drought in Northern parts of Ethiopia}

The effects of drought are widespread and have devastating effects on the environment and the society as a whole. Water use is part and parcel of almost every human activity as well as the life of plants and animals. On this basis, extended deficiency of water can affect the society in various ways both directly and indirectly. Because water is one of the most essential for human survival, second only to breathable air. So when there is a drought, which by definition means having too little water to meet current, demands, conditions can become difficult or dangerous very quickly. Generally effects of drought can be categorized in northern parts of Ethiopia as environmental, economic, social and political effects.

\subsection{Environmental Effects of drought in NPE}

Drought affects various components of ecosystems and environments. Environmental losses are the result of damages to plant and animal species, wildlife habitat, air and water quality and quantity, forest and range fires, degradation of landscape quality, loss of biodiversity and soil erosion. Some of these effects are short-term conditions returning to normal following the end of the drought. Other environmental effects last for some time and may be become permanent. The availability of water level in reservoirs, in lake, in river, amount of rainfall, soil moisture and ground water depths are some of the environmental indicators of drought. Drought reduce water 
quality in the wetland areas for example lakes, rivers, reservoirs and ponds and also groundwater table but also reduce soil moisture contents; reduction of human life, animal life and plants life. Biodiversity depends on various forms of water, including moisture in soil and atmosphere, for their survival. There may be permanent and temporal impacts on biodiversity depending on the duration, intensity and scale of drought. Reduction in water may alter the food supply to different life forms, which may subsequently alter the food web, animals, especially wildlife may become susceptible to diseases due to shortage of water and so that the foodstuff, there may be change in distribution of due to short supply of water, species which have low population size and narrow range of distribution further decline in their number due to stressful climate condition and shrinking of wetlands may decline the aquatic flora and fauna and also at the same time increase in forest fires due to increasing temperature and low humidity may decline the forest and wildlife species.

Drought impacts the groundwater level and frequent droughts compel farmers and other community groups to extract aquifer, which deplete the groundwater table. Depleting groundwater further leads to ecological damage such as land subsidence and loss of springs and wetlands. Some major effects of environmental drought in northern parts of Ethiopia for long times are drying out of water bodies, reduction in soil quality, unsuitable condition for human, plants and vegetation survival and migration and even death of human, animals and wildlife.

Unsuitable condition for human, plants and vegetation, drought conditions make it unsuitable for human, plants and vegetation cover to survive. Besides, fertile lands are lost as a result of drought and in consequence desertification sets in. desertification is whereby the lands become infertile and bare, frequently as a result of overgrazing and is exacerbated by drought which makes it difficult for such lands to recover.

Migration and even death of human, animal and wildlife, people, animals and wildlife are forced to migrate in drought conditions since they have to for long distances to get water and food. The prevailing circumstances during droughts also make it difficult for survival of the animals. When the peoples, wildlife and animals migrate, they end up in new locations where they can be vulnerable, endangered because of new threats. This leads to loss of biodiversity and disruption of natural ecosystems.

Generally, change in environmental ingredients at one locality may affect the environments of other locality by different means. There are records of abrupt elevation in dust and chloride levels during drought conditions and the air pollution generated at one part of the world due to number of reasons affects the life of people on another. Sulfate aerosols offset some global warming by cooling atmosphere but at same time they also contribute to drought in many regions. There are some reports which claim that air pollution from Europe contributes to developing countries, like Ethiopia country. Due to these reason the increase in temperature and subsequent loss of water is catastrophic to almost all the natural ecosystems, especially the sensitive ecosystems and so that the sensitive crops and species.

\subsection{Economical Effects of drought in NPE}

Economic impacts of droughts are realized from monetary and business losses incurred during drought by individual levels, families, businesses and governments. Many economic impacts of droughts in northern parts of Ethiopia occur in agriculture and related sectors, because of the reliance of these sectors on surface and groundwater supplies. Agriculture in northern parts of Ethiopia is the many source of economy. Majority of people in Ethiopia still live in rural areas where agriculture is one of the major professions for livelihood. According to (Sadoff, 2006), More than $85 \%$ of total population depends on agriculture for their livelihood, either directly or indirectly in rural and urban areas in Ethiopia, However, they have rain fed agriculture system, which is highly affected by droughts every year staring from 1985 up to now. Therefore, during droughts, most farmers in northern parts of Ethiopia spend more money on crop irrigation so as maintain crop yields and also lots of water has to be availed for watering the farm animals to ensure the daily water consumption standards are met. Hence, farmers have to spend more money to buy water or drill wells to keep the crops and livestock nourished with enough water and also for water supply of their domestic purposes, such as drinking, cooking and etc. Often low crop yields are experienced during drought periods. Therefore, farmers usually undergo major economic losses because of low crop yields. They pay for lots of inputs and labor, but the outcomes are less. People, who depend on forest resources, including non timber forest produce, may not get such resources in order due to shortage of water for quality production of forest produce during drought years.

Industries and businesses in farm equipment manufacturing and merchandising respectively loss millions of Ethiopian birr when farmers lack the money to buy their resources. Governments, on the other hands have to allocate more money and spend even more for drought mitigation as they have to cushion the farmers and the entire society from the adverse impacts of the droughts. Such governmental monetary spending includes funds for emergency supplies, seed funds and availing other relevant drought mitigation resources.

Extended dry spells can translate to lowered water levels in rivers and dams used to generate hydro-power. This means higher costs of energy for businesses because the hydro-energy companies are driven to operate below capacity. Businesses at time have to use fuel-powered generators which result in higher business operation costs. At the same time increased energy demands lead to increased cost of grid energy, which leads to economic losses 
both for energy industries and businesses.

The impacts of drought are not uniform across in northern parts of Ethiopia rather it change according to the geographical and status of the society. Changing farming patterns in drought-prone areas are also subjected to increase adverse effects of drought especially Tigraye, Afar and northern parts of Amara regions in 2015-2018. Most of time this place needed to support from government like, food and different materials from other parts of countries, internal government and out of the countries governments and World Bank also support this parts of Ethiopia many times. Form this area many animals are died such as goats of farmers before many years, we see below picture.

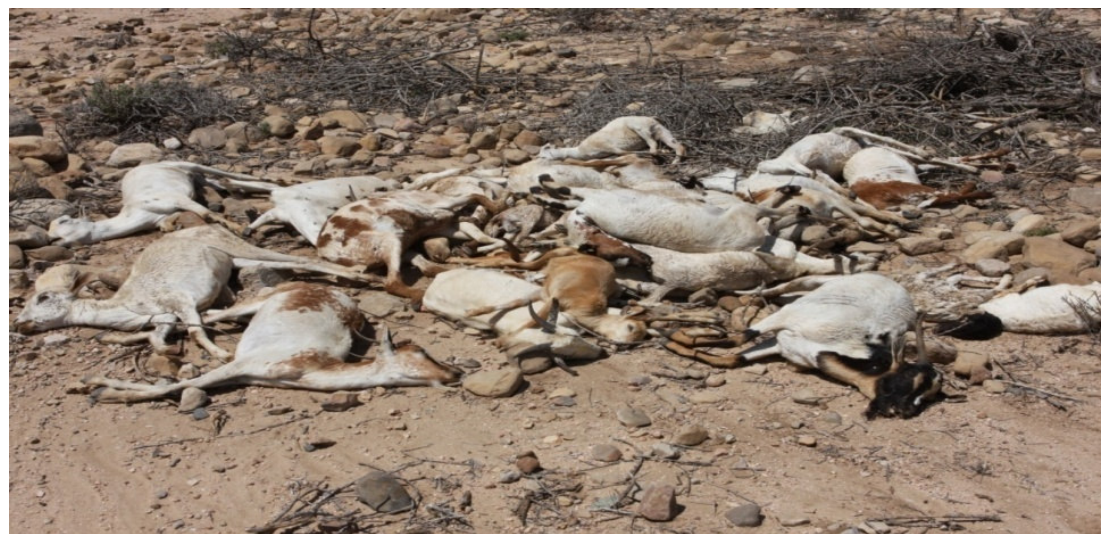

Sources: Feb 22, 2016, Ethiopia is in the grip of a devastating drought sparked by the worst

This is damages of economies of the farmers during drought time in northern parts of Ethiopia starting 1985 up to now, not only these there are many animals are died.

Generally, economical drought impacts conditions of nations at local to global scale. It may affect the people not only living in the drought-stricken areas but also those who live outside the drought areas as they may also depend on drought stricken areas for their livelihood for different means of their economies.

\subsection{Social Effects of drought in NPE}

Social impacts of drought involve public safety, health, conflicts between water users, reduced quality of life and inequities in the distribution of impacts and disaster relief. Many of the impacts identified as economic and environmental have social components as well. People are forced to shift to other places in search for better living conditions during droughts, often stimulated by a greater supply of food and water elsewhere. This contributes to loss of livelihoods and disorients small scale farmers who are dependent on their farm produced. People forced to migrate to urban areas within the stressed or to regions outside the drought area also undergo lots of stress, anxiety and are compelled to indulge in strenuous activities to provide for their families. Women, children and the elderly are the most affected in this area most of time, especially in 2015, 2016 and 2017. The drought migrants place increasing pressure on the social infrastructure of the urban areas, leading to increased poverty and social unrest.

Social impact of drought is causes of waterborne diseases, since water scarcity is high during drought condition, water quality significantly decreased. This means the availability of clean water for drinking and water for sanitation and cleaning may not be sufficient. Drought also increases the concentration levels nutrients, chemicals and soil particles or impurities in surface waters. As a result, managing and preventing waterborne diseases such as Typhoid, Amoeba, Guardia and Cholera becomes increasingly rapidly, especially in poor communities in this area. And also cause huger, anemia, mortalities and death of people are often witnessed in drought stricken areas. Drought is a great causal factor for low food production, thus, when experienced in poorer communities are affected every year in NPE. Often, it is as a result of lack of sufficient food nutrition that directly contributes to diseases and health vulnerability. Common cases of hunger, anemia, malnutrition, and mortalities are recorded in poorer regions. The widespread malnutrition due to low production during drought makes people vulnerable to diseases. Drought may also force people to sell their property in return of saving life. The weaker section of the society is more prone to suffer from the adverse impacts of drought because they do not have enough resources to sustain during drought period. At the same time, the rich people may exploit the poor people by taking undue advantage of prevailing drought and its aftermath. There are number of cases where farmers commit suicides due to extreme situations in northern parts of Ethiopia most times. In some drought-hit villages the girls even married off at the age below 15 due to scarcity of resources to feed her and boys migrate into urban areas. Apart from creating physical and mental stress, the reduced supply of water may create social conflicts within the community, which may become irreparable. People may be forced to reduce their daily water use, which make them to feel that they are in the low priority of the government.

The dependency on water tankers have made people to wait most of time for fetching daily water consumption for their domestic activities from far distances, which created disturbance among the people and also consumed 
their time. Besides, they consumed the bore well water without filtering which made them susceptible for diseases most people. Still the shortages of water supply in northern parts of Ethiopia is very hard, not only this as whole parts of Ethiopia for each year in both rural and urban areas, then most people fetch water from unprotected and un cleaned sources.
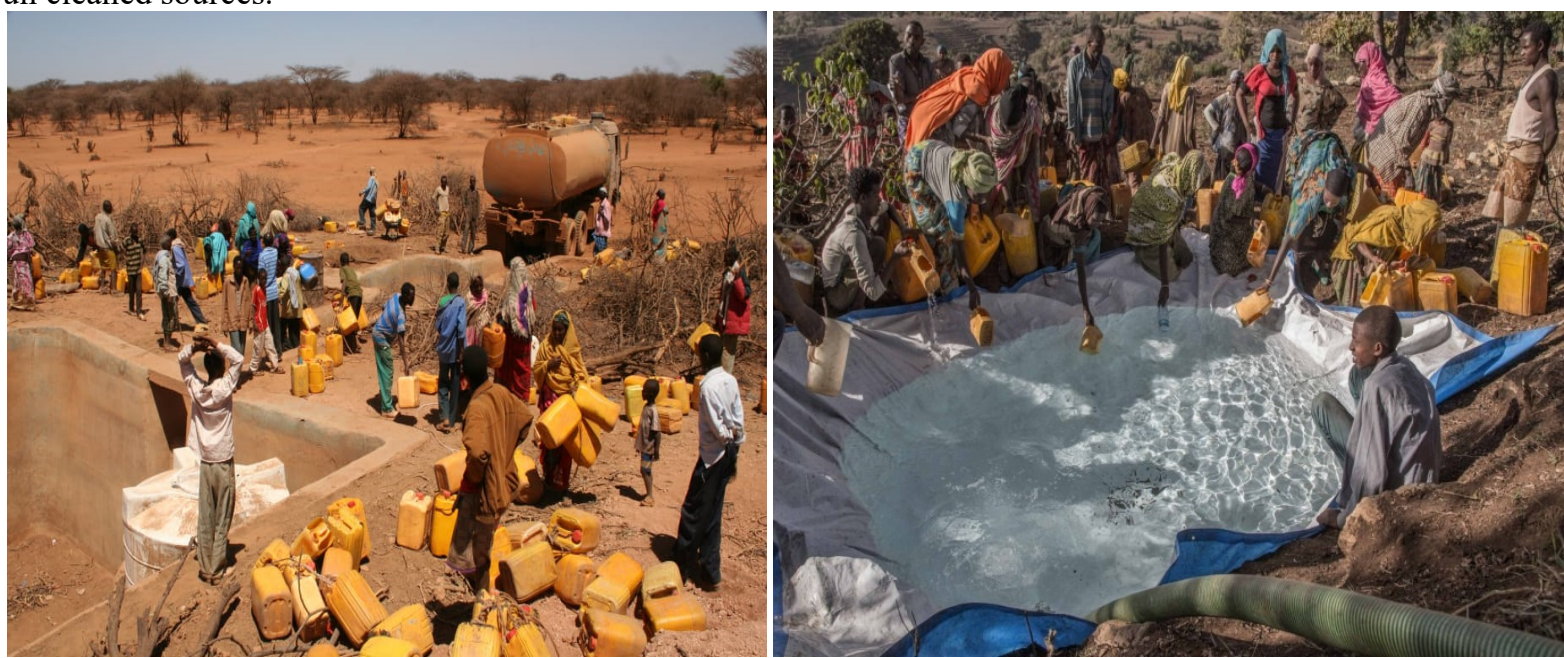

Sources: Feb 22, 2016, Ethiopia is in the grip of a devastating drought sparked by the worst

This picture show shortages of drinking water supply in study area, this condition still exist more parts of Ethiopia country, especially northern parts of Ethiopia by different time and up to now in northern parts of Amara, Tigraye and Afar region the whole parts.

Generally, social effects of drought are affects directly or indirectly the human being as whole in drought areas and out said drought areas by different means, like scarcity of food and shortages of water supply by drinking purpose, irrigation, animals, freely breaths of air in urban areas, loss of human life, reduced incomes, minimize recreational activities and etc.

\subsection{Political Effects of drought in NPE}

The current drought in Ethiopia has already affected the country's energy and agriculture sectors. The area specifically northern parts of country are now facing possible supply shortages as the drought continues. A few solutions can be implemented in the short term. The government is likely to promote conservation measures and increased water rationing appears unavoidable. This could negatively affect the ruling party of country. Most of time the leaders who lost their power by regular exits or irregular exits and losing power through all other types of exits, during this time people ask more questions the government and keep the response immediately. But government has no power to fulfil the people needs at once time, at this time conflict is created between people and government by different means. Generally drought is one problem to drop politics of the governments because the drought area people cannot access the politics without fulfillments of their needed and without prevents the drought or give a new place for living and money for survive at new place or old place after drought is stopped. Therefore the government must be fulfilling needed of drought areas by itself or boring money from other developed countries government or World Bank. The government does not do this types of activities the political is dropped and affected in case of drought especially this is common in Ethiopia country most time still nowadays in northern parts of Ethiopia and as whole boarder parts of country.

\section{Mitigation of drought in NPE}

The word mitigates means making something less painful, severe or serious. Thus, drought mitigation strategies are things that can be done to lessen the force or intensity of dry periods. Some drought mitigation strategies, such as building dams, alter the landscape forever. Others require human behavior to change. Many drought mitigation strategies are expensive and taxpayers are the ones who pay the bill for their implementation. It's important that citizens can judge the cost and benefits of different drought mitigation strategies so they can support responsible planning for protection from drought. Some of drought mitigations are as follows:

$>$ Using water properly for drinking, irrigation and industrial supplies

$>$ Harvesting rain water and developing technical advanced structures for storing water for future time

$>$ Protect natural water bodies such as lakes, rivers, ponds and other wetland areas

$>$ To give awareness for farmers about the drought and anticipation of drought

$>$ A proper monitoring of local and regional climate is required to generate such information for onward transmission to farmers

$>$ To exchange seed of crops through a time 
$>$ To create awareness from total communities about drought, causes of drought and impacts of drought on their life, economy and environments

$>$ Forestation of new plant which adapts the drought by each or per person

$>$ To use new farming practices that require less water to growth crops and resists the drought when drought is occur suddenly

$>$ Investing the research of climate change and drought for most time because to now the current cause of climate change and drought and also prevent easily during starting time

\section{Conclusion}

Drought is a natural disaster due to manmade causes that has to be dealt with globally. The northern parts of Ethiopia have been facing the adversities of frequent drought for past of some decades and recently in 2015, 2016 and 2017 under severe drought situation. The worst drought is happened in north parts of Ethiopia in 2015, affecting nearly 10 million people, the dry conditions left hundreds of thousands of farmers with failed crops and weakened or dead their livestock. The resulting food scarcity meant more than eight million people in the parched country needed emergency food aid. The major causes of drought in northern parts of Ethiopia are lack of precipitation, increase total dry days, prolonged dry spells, high evapo-transpiration, climate change, drying out of surfaces water flow, high food prices in market and lack of knowledge about adaptive farming techniques. Most of the agriculture land being rain fed, its productivity is heavily dependent on climate and rainfall. However, the impacts of drought are not restricted to the agriculture sector alone but they spread out to other sectors, including forestry, tourism, energy, health, environment, social, marketing and economics. This leads in northern parts of Ethiopia, the drought brings food crisis, affects people's health, invites social conflicts and sometimes compels farmers to take harsh steps such as committing suicides.

Therefore, to reduce these types of drought in study area is using different mitigation strategies with different mechanisms for next time or future time depends on their economic status and their knowledge to easily understand and uses properly. Then the people could be use the water resources of surfaces and groundwater properly without wastage, Rain water should be harvested in each and every household, revival of traditional water conservation structures and development of technically advanced structures for water storage, the excess water during monsoon if stored in the aquifers it can be used via tube well during the dry spells. Interlinking the rivers, crop diversification and development of drought resistant crop varieties can help to mitigate the adverse impacts of drought. And also the farmers must be increase the share of irrigated land, especially by expanding drip irrigation facilities for proper utilization of available water resources.

Therefore, in study area more and more trees should be planted as to maintain the soil moisture and quality of the soil. Planting trees is very important to maintain the water table beneath of groundwater. The emission of green house gases should be banned as to reduce global warming and drastic change in climate. The soil moisture should be checked regularly so that early sighs of drought gets indicated.

To create awareness from the total communities regard to causes and effects of drought on their life, economy, social aspects and environmental, Awareness programs should be conducted regularly so that people will be aware of the importance of water and forestation of plants and properly uses of them and also different purposes them through their life and for future time for next generation.

After this the government must be implement the proper measurements of check misuses of both water resources of ground and surfaces water and rainwater during rainy season, planting of trees and deforestation of trees around this areas, to check the weather condition at least once a month, to produces a new technology instead farming all areas, to apply the experiences of different developed countries to protect or mitigate the drought when it happened easily and motivate different researchers to study and to solve this problems for long time as well as whole country, especially the border regions of country.

\section{REFERENCES}

Abdel Ghaffar M. Ahmed Alemayehu Azeze Mustafa Babiker Diress Tsegaye (2002), A review post -drought recovery strategies among the pastoral households in the horn of africa:

Abebe Zegeye; Pausewang, Siegfried (1994). Ethiopia in Change: Peasantry, Nationalism and Democracy. London: British Academic Press. ISBN 1-85043-644-4.

Amarnath, G. and Clarke, J. 2016. Uncertain water: Dealing with increasing floods and droughts demands new thinking and new technologies. Times of India, April 30, 2016.

Aldaya, M.M. (2017). Eating ourselves dry. Nature, 543: 633-634.

Andargachew Tiruneh (1993). The Ethiopian Revolution, 1974-1987: A Transformation from an Aristocratic to a Totalitarian Autocracy. Cambridge: University Press. ISBN 0-521-43082-8

Berhanu Admassu, Gezu Bekele, and Dawit(2014), Abebe1Livestock mortality in pastoralist herds in Ethiopia and implications for drought response Andy Catley,

Clay, Jason; Holcomb, Bonnie (1986). Politics and the Ethiopian Famine 1984-1985. New Brunswick and Oxford: 
Transaction Books. ISBN 0-939521-34-2.

Causes and Characteristics of Drought in Ethiopia, [1988]

Dalin, C., Wada, Y., Kastner, T., and Puma, M.J. (2017). Groundwater depletion embedded in international food trade. Nature, 543: 700-704.

Ethiopia HRD 2017: Status Update, 19 October 2017

Ethiopia Food Security Outlook, June 2018 to January 2019

Ethiopia Food Security Outlook Update, August 2018

Ethiopia: Agriculture Sector Monthly Gap Analysis - Livestock Intervention (October 2018)

Ethiopia: Agriculture Sector Monthly Gap Analysis - Agriculture Emergency Seed and Tools Intervention (October 2018)

Ethiopia - Drought response plan and priorities in 2017

Ethiopia: Agriculture Sector Monthly Gap Analysis - Livestock Intervention (October 2018)

FAO Ethiopia Drought response plan and priorities in 2017 - Revised version, August 2017

Feb 22, 2016 ... Ethiopia is in the grip of a devastating drought sparked by the worst El ... The drought is caused in part by the El Niño warming phenomenon ... "We have got a really, really bad drought, but we can head off the consequences

FEWS NET (2016) Ethiopia food security outlook October 2016 to May 2017. Famine Early Warning Systems Network (www.fews.net/east-africa/ethiopia/food-security-outlook/october-2016).

Finn, James (1990). Ethiopia: The Politics of Famine. New York, NY: Freedom House. ISBN 0-932088-47-3

GIZACHEW LEGESSE(2010), Agricultural drought assessment using remote sensing and GIS techniques

Gryseels, G. and Anderson, F. 1983. Research on farm and livestock production in the central Ethiopian Highlands. Initial results 1977-80. ILCA Research Report No. 4, ILCA, Addis Ababa.

Horn of Africa: A Call for Action, February 2017 [EN/AR]

Horn of Africa Climate Crisis, Regional Summary \#14 (August/September 2018)

HRD (2016) Ethiopia 2016 humanitarian requirements document. [Addis Ababa]: Government of Ethiopia and Humanitarian Partners

In 1982 the International Livestock Centre for Africa (ILCA) established a Livestock Policy Unit (LPU). Livestock losses and post-drought rehabilitation in sub-Saharan Africa LPU Working Paper No. 9

IOM East and Horn of Africa Drought Appeal April - December 2017 [EN/AR]

Jamwal, N. (2016). Marathwada's dry story. Down To Earth, 24 (24): 8-13.

Jain, B. 2017. 2015 drought effect: sugar yield sees worst fall in 10 yrs, prices set to rise. Times of India, April 3, 2017.

Kala, C.P. (2011). Save Ganga campaign and hydroelectric projects in Uttarakhand. Current Science, 101 (5): 596.

KSNDMC. (2016). Karnataka State Natural Disaster Monitoring Centre (KSNDMC), Bangalore, Karnataka. https://www.ksndmc.org.

Mid-Year Review, Ethiopia Humanitarian Requirements Document, July 2017

May 8, 2017 ... Ethiopia Drought: Fact Sheet - May 2017. Situation. • After El Niño-driven weather caused one of the worst droughts in many parts of Ethiopia

NIDM 2010. National Disaster Management Guidelines: Management of Drought. National Disaster Management Authority, Government of India, New Delhi.

National Meterological Service Agency (NMSA). (1996). Assessment of drought in Ethiopia. In: Meterological research report series No.2.Addis Ababa.

Pritchard,. H D. 2017. Asia's glaciers are a regionally important buffer against drought. Nature, 545: 169-174.

1Pritchard, H.D. 2017. Asia's glaciers are a regionally important buffer against drought. Nature, 545: 169-174.

Reddy, M.S. and Kidane Georgis (1993). Climate, Soil and Crops of the main Dryland areas. In: Dryland farming research in Ethiopia.Institute of Agricultural Research, Addis Ababa.

Sadoff, C. (2006). Agricultural and rural development: Can water Undermine Growth? URL:http://www.google.com/search?client=firefox-a\&rls=org.mozilla\%3Aen-

Segele, Z.T. and Lamb, P.J. (2005). Characterization and variability of Kiremt rainy season over Ethiopia. Meteorology and Atmospheric Physics, 89:153-180.

SNDMC 2016. Karnataka State Natural Disaster Monitoring Centre (KSNDMC), Bangalore, arnataka. https://www.ksndmc.org

Siddiqui, K. 2015. Agrarian Crisis and Transformation in India, Journal of Economics and Political Economy, 2 (1): 3-22.

Tallaksen, L.M. \& van Lanen, H.A.J. (Eds.) (2004) Hydrological Drought. Processes and Estimation Methods for Streamflow and Groundwater. Developments in

USAID/Ethiopia Agriculture Knowledge, Learning, Documentation and Policy Project (2016) El Niño in Ethiopia, 2015-2016 - A real-time review of impacts and responses. Feed the 28. Future(www.agri-learningethiopia.org/wp-content/uploads/2016/06/AKLDP-El-Nino-Review-March-2016.pdf). 
US\%3Aofficial\&channel=s\&hl=en\&source=hp\&q=Sadoff $+\% 282006 \% 29 \% 2 \mathrm{C}+80+$ percent +of+Ethiopia $\%$ E2\% $\% 0 \% 99 \mathrm{~s}+$ population+subsists + on + rainfed +agriculture \&btnG $=$ Google + Search

World Meteorological Organization (WMO). (1986). Report on drought and countries affected by drought during 1974-85.WCP-118.WMO/TD-No.254, Geneva.

Wilhite, D. A. and Glantz, M. H. (1985). Understanding the drought phenomenon: The role of definitions. Water International, 10:111-120.

WMO, 1986; NMSA, 1996). WMO statement on the status of the global climate in 1986 and 1996

World Meteorological Organization (WMO). (1986). Report on drought and countries affected by drought during 1974-85.WCP-118.WMO/TD-No.254, Geneva.

Yimer Mohammed, Fantaw Yimer, Menfese Tadesse, Kindie Tesfaye, (2017) "Meteorological drought assessment in north east highlands of Ethiopia", International Journal of Climate Change Strategies and Management, https://doi.org/10.1108/IJCCSM-12-2016-0179 